\title{
Border Security and Migrant Smuggling: A Study on Illegal Immigrants in the Northern Region in Peninsular of Malaysia
}

\author{
Mohd Na'eim Ajis ${ }^{1}$, Ummu Atiyah Ahmad Zakuan ${ }^{2}$ and Zawiyah Md. Zain ${ }^{1}$ \\ and Mohamad Faisol Keling ${ }^{2}$ \\ ${ }^{1}$ School of Government, College of Law, Government and International Studies, Universiti Utara Malaysia \\ ${ }^{2}$ School of International Studies, College of Law, Government and International Studies, \\ Universiti Utara Malaysia
}

\begin{abstract}
Migrant smuggling is a trans-border crime which yields enormous amount of profit. Migrants who enter a country through this method are classified as illegal immigrants. Thus, security border of a country needs to be continuously enhanced and improved to prevent the occurrence of human trafficking. Hence, this article discusses about migrant smuggling activities in the Northern Region of Peninsular Malaysia. Issues discussed include countries and borders that involved in the smuggling of migrant, types of transportation used, charges paid to the syndicates, parties involved in the process and the tactics of human smuggling. The data of this study are taken from fifty five illegal immigrants who are being detained at the Immigration Detention Centre at Sik, Kedah and those who settled in several districts in the Northern part of the Peninsular Malaysia. Relevant authorities like Malaysian Maritime Enforcement Agency, Malaysia Immigration Department and Border Ranger Regiment, are being interviewed. Findings reveal that the activities of migrant smuggling are occurring in the Northern Region of the Peninsular Malaysia. The authorities are continuously improvised the monitoring methods to curtail the migrant smuggling however, the syndicates are often ahead of the authorities and getting difficult to be traced.
\end{abstract}

Keywords: Migrant Smuggling, Border Control, Immigration, Illegal Immigrant, Malaysia

\section{Introduction}

Border control is a part of a migrant control policy and associates closely with sovereignty and security of a country. Any mistake occurs in controlling borders will result in the occurrence of trans-border crimes including migrant smuggling and drugs trafficking as well as terrorism. Recently, migrant smuggling expands widely until it becomes trans- border crimes. Migrant smuggling involves taking, moving and transporting migrants from the sending countries to the receiving countries (Shelly, 2014). Migrant smuggling emerges as a well-known crime due to its enormous profit generation to the traffickers. Payments to the traffickers are not fixed but depending on the facilities, transportation, levels of difficulties, security risks and distance of the destination. However it is reported that, migrant smuggling from China to the United States could reach up to USD 70,000 per head (Petros, 2005).

The issues on illegal immigrants and smuggling have been discussed by many scholars of international migration and most of them agreed that smugglers play an important role in transporting the immigrants to the country of destination. Normally, the smugglers will provide various facilities such as transportation and documents (Heckmann, 2007). Therefore, most countries have strengthened or tighten their migration policies including that of border control. This practice has indirectly increased the cost of migration subsequently contributing to the occurrence of smuggling. By tightening border control, it will yield various implications mainly increasing the number of illegal migrants in a country and the widespread of bribery. This article mainly 
aims to analyze and identify the migrant smuggling activities in the northern region in Peninsular Malaysia and the extent of the border control in the said areas. Several issues are being discussed in this paper including the entry point, borders used in the smuggling activities, charges paid to the agents, and transportation used in the smuggling activities. These elements are vital in giving a clear picture on smuggling activities at the borders.

\section{Border Control and Smuggling of Migrants}

Border control is one of the aspects in the migrant control policy of a country. Brochmann (1998) states that there are five main elements in migrant control policy, both in countries of origin and countries of destination. It covers country of origin, policy control of country of destination, entrance control at the point of entry of a country, control of migrants in employment sectors and lastly expiry policy. Hence, these dimensions will result in two types of policy approach, whether it is flexible or rigid. Tholen (2010) states that there are two main objectives in producing migrant policy, which are, to produce effective policy and to prevent negative policy implication. Every country must ensure that every migrant policy achieves its desired goals. Cornelius and Tsuda (2004) argued that if the output of migrant policy are not met, then it will create a policy gap. As the gap grows, the bigger challenges a government will encounter. In terms of illegal immigrant issues, it is undeniable that many countries have increased border control and strengthen the migrant policy as one of the main instruments in containing illegal immigrants and the smuggling activities. Nicole Piper (2004) argues that by

strengthening the border control, visa application and exit-entry point control actually pose several adverse impacts. First, it contributes to a higher occurrence of human trafficking and the smuggling of persons. This is due to proper planning and systematic strategies that employed by the smugglers to overcome the existing structures. Second, a strict control at the borders will encourage illegal immigrants to stay longer in a country because they will try to reduce the risk of exit-entry activities in destination country.

Controlling illegal immigrants and smuggling activities in Malaysia have been monitored by the government from time to time. The control can be categorized into internal and external aspect. Internal control refers to the policies that the government introduced such as Ops Nyah 1 that concerned border control while Ops Nyah 2 related to the apprehended of illegal immigrants. The immigrants were encouraged to surrender and granted pardon and returned to their respective countries of origin legally. In 2005, the illegal immigration management system has been revised and many changes have been introduced. One Stop Centre (OSC) in the Ministry of Home is responsible to filter the application to employ the immigrants (Azizah Kassim, 2012). In 2010, the Cabinet Committee for Foreign Labour-Illegal Immigrants has decided that Visa on Arrival (VOA) is not issued to certain countries which have higher likelihood to produce illegal immigrants, such as China, India, Nepal, Bhutan and Bangladesh. The Malaysian government confides that many foreign immigrants are actually foreign tourists who have misused their VOA through overstayed to work (Utusan Malaysia, 13 August 2010). In 2011, the Minister of Home had taken an initiative to introduce Illegal Immigrants Comprehensive Solution Program or known as the 6Ps program, consisting registration, legalization, amnesty, monitoring, enforcement and deportation. This programme is vital in dealing with the illegal immigrants, in which until now it yielded any concrete solution (Angelina Sinyang, 2011).

\section{Methodology}

This study focuses on the northern region of Peninsular Malaysia, mainly in Penang, Kedah and Perlis. It uses primary and secondary data which are collected in several ways. Interviews with the relevant agencies such as Malaysia Immigration Department (MID), Anti-Smuggling Unit (UPP), Malaysia Armed Forces (ATM) and Malaysia Maritime Enforcement Agency (MMEA) were also conducted. Data also was collected through document study on various academic writing, newspaper cutting, agencies publication and legislation relating to the immigration and illegal immigrants management. Respondents of this study are the illegal immigrants who are being detained at the Belantik Immigration Detention Centre, as well as those who are at large particularly 
Rohingya's refugee ${ }^{1}$. There are 54 persons selected in the study which represent approximately 10 per cent of the total 543 detainees at the depot. This study also employs observation as to get information relating to the activities of the illegal immigrants. Among the approaches taken were visiting the entry border points, routes that used in smuggling and the communities which display direct or indirect involvement of the illegal immigrants. The areas covered were Langkawi Island, Kuala Kedah, Penang, Sungai Petani, Alor Star and few other premises and construction sites around Kedah and Perlis. The areas and places were selected based on the findings of previous studies and preliminary findings of this study that these places were the favorite and concentration of the illegal immigrants. All data are analyzed using the descriptive and analytical approach. The interview's and focus group's data are analyzed using thematic sequence basing on the research objectives.

\section{Analysis and Findings}

The study focuses on the illegal immigrants who entered Malaysia. The analysis revolves on the routes and transportation that being used, entry point, countries involved to reach Malaysia and agencies involved in the smuggling.

\subsection{Routes and Transportation Used}

Air route was the most favored route to reach Malaysia. Most of the respondents revealed that they used the air route using the services offered by employment agencies. They come as far as Africa and the Middle East. While the land and sea routes are more popularly used by the migrants from ASEAN countries such as Indonesia, Thailand, the Philippines, Myanmar, Vietnam and Cambodia or from the South Asia, like India and Bangladesh. The competition in the aviation industry has made the price of air tickets relatively low and affordable simultaneously stimulates migration. ${ }^{2}$ Besides the common ways to enter Malaysia, they also used fake passports. This is a widespread practices among those who came from Myanmar, in particular, the Rohingya, who are denied citizenship by the Myanmar government. Once entered Malaysia, they will dispose the passports and applied asylum to obtain refugee status at the United Nations High Commission for Refugees (UNCHR) office.

The migrant smuggling activities have taken place at the KL International Airport (KLIA) and the Low Cost Carrier Terminal (LCCT) as have been exposed in the media. These smuggling activities are due to the corruption practiced by the Malaysian Immigration Department (JIM) officials. ${ }^{3}$ The officials involved were claimed to receive hundred thousands of financial incentives on monthly basis from employers and agents who wanted to get foreign workers. (Wan Noor Hayati Wan Alias, 2013). According to the Malaysia Employer Federal (MEF), smuggling activities and bribery at the airport are very common in migration. The cause of this is bureaucratic practice in managing foreign workers forcing the agents and employers to bribe the authority to precipitate the process (Mohd Nasaruddin Parzi and Wan Noor Hayati Wan Alias, 2013). Immigration Department of Malaysia, however claims that, the bribery is not widespread but only among certain individuals and do not reflect the entire practice of the department. ${ }^{4}$ As for the sea route, the respondents revealed that they used boats or barge to enter Malaysia. However, this mode is too risky as it can be easily suspended by the authority but also exposed to danger which sometime fatal. ${ }^{5}$

\footnotetext{
${ }^{1}$ Since Malaysian Government does not ratified the Convention Relating to The Status of Refugees also known 1951 Refugee Convention, hence, status of refugee in Malaysia still remain as illegal migrants.

${ }^{2}$ Castle (2004) states that globalization has caused the air ticket lower in price and easily accessible.

${ }^{3}$ This situation is in line with Boswell and Sraubhaar (2004) who think that the increase border control of a country can prevent the entry of illegal migrants but at the same time bring side impacts mainly bribery.

${ }^{4}$ Interview with Zahari Abdul Aziz, Director at the Enforcement Unit, Malaysia Immigration Department, Malaysia Immigration Head Quarters, Putrajaya, $2^{\text {nd }}$ June 2014

${ }^{5}$ Koser (2008) who examined about the Pakistanis who were being smuggled into Western Europe admitted that most of the respondents agreed that the sea routes are very risky and dangerous. Despite of the danger, the respondents admitted that the sea route is very popular due to lower cost.
} 


\subsection{Borders Crossed}

Bukit Kayu Hitam and Padang Besar, at the northern area Peninsular Malaysia, are the land routes used by the migrants to enter Malaysia. Some of them entered via Malaysian airports such as KLIA (Kuala Lumpur), LCCT (Kuala Lumpur), Sultan Abdul Aziz airport (Selangor) and Bayan Lepas airport (Penang). Golok River, Klang, Pasir Gudang and Penang Port are the popular entry points for the sea route. The routes selected reflect the status of the migrants. For instance, those who travelled by using land routes are most likely not having valid travelling documents. While those who travelled by air, often come via social visit or student pass.

Malaysia-Thai border is the main choice for migrants from Bangladesh, Myanmar, Cambodia, Vietnam and Thailand. The border has three main routes namely Golok River, Bukit Kayu Hitam and Padang Besar or Chuping which are used for smuggling activities. According to Bukit Kayu Hitam Border Regiment officers, the immigrants move in small group, from four to five persons, to enter the Bukit Kayu Hitam border, they cut the fence and sneak in at night. The smuggling activities normally occurs at night particularly at Perlis border and Bukit Tangga Felda settlement. The migrants will come in group from Thailand and gone into hiding in an areas before cutting the fence and escape into Malaysia illegally. ${ }^{6}$ However, some enter through legitimate entry at the border and headed to the Free Duty Complex, Bukit Kayu Hitam, Kedah. They normally used the lake near the Black Forest Golf and Country Club and penetrate further into Kedah via broken fences. ${ }^{7}$

Meanwhile, most of the illegal immigrants who are smuggled into the country, do not know their whereabouts because the operation was carried out at night and was monitored closely by the syndicate. Hence, to identify the routes used by the smugglers, the authority has identified several terms to signify the place of destination. For example, "sugar cane estate" (ladang tebu) in Chuping, Perlis; "jungle" (hutan) in Ladang Temin, Bukit Kayu Hitam Kedah and "river" (sungai) at the borders of Golok River, Kelantan. Basing on the terms, the authorities are able to identify which route that is used by the illegal immigrants to enter Malaysia. ${ }^{8}$

\subsection{Countries Passed Before Reaching Malaysia}

Most of the illegal immigrants came directly to Malaysia because they are brought by agents to work in the country. However, some of them have stopped at other countries before reaching Malaysia. From the data gathered, most of them are from Myanmar who came through Thailand before entering Malaysia. Thailand is perceived by many illegal immigrants as a transit country among those from Indochina such as Myanmar, Vietnam, Cambodia and Laos. It is due to its sharing border with Malaysia and furthermore, some of them even reside, married and worked in Thailand. The findings of this study suggests that apart from the illegal immigrant who came through Thailand from China and Mongolia. They came through Thailand and stayed there before entering Malaysia. Normally they stay around 3 to 4 years and mastered the local language. ${ }^{9}$

\subsection{Operating Party, Charge and Smuggling Tactics}

Most of the respondents stated that they used employment agents because they came to Malaysia due to economic reasons and obtained Temporary Work Permit (TWP). However, some of them came via smuggling syndicates. According to Immigration Department, anybody who from taxi or bus driver, civil servants, individual or the locals, could be smuggling agents or tekong darat. This has made their movement is hardly being traced by the authority, particularly those with the syndicates. The charges imposed by the smugglers at the border is approximately between RM500-RM2000 ${ }^{10}$ depending on the assistance been provided by smugglers like transportation, food, accommodation and security risk. The charges will be shared with

\footnotetext{
${ }^{6}$ Interview with Border Regiment Officers at Border Regiment Office, Bukit Kayu Hitam, $9^{\text {th }}$ June 2010

${ }^{7}$ Since two years ago Black Forest management had taken necessary measure by built 2.5 kilometers length of wall by replacing old fence. However, according to Immigration Department the wall was not follow the immigration specification of border security and finally, the problems of illegal migrants and smuggling activity still cannot be solved. In the same time researchers failed to catch up the Black Forest Management to get their comment on their area been used for smuggling.

${ }^{8}$ Interview with an Immigration Department Officer on the $21^{\text {st }}$ May 2010 at Bukit Kayu Hitam Immigration Office, Kedah

${ }^{9}$ Interview with Immigration Officers on the $21^{\text {st }}$ May 2010 at Bukit Kayu Hitam Immigration Office, Kedah

${ }^{10}$ These amount not included the charge been paid to the agents in home country.
} 
smugglers or tekong darat from Malaysia and Thailand. ${ }^{11}$ According to Border Authority, some of the smugglers can anticipate the patrol time made by authorities at the border of Bukit Kayu Hitam, Kedah. Houses which are located along the border's fences are believed to be used by the smuggler to place illegal migrants before entering or being smuggled into Malaysia. Some of the respondents informed that they were being stationed there before being transported into Malaysia. In 2015, Malaysia was shocked by the discovery of mass graves near Malaysia-Thailand border. Malaysian authority has informed that those illegal migrant who are going to be smuggled will be placed at a camp near to Malaysia-Thailand border. The syndicates will wait for the ransoms prepared by the families, relatives or even friends of the migrants, before they are being smuggled (Utusan Malaysia, 24 May 2015).

\section{Conclusion}

Based on the discussion above, it is apparent that border control relates closely with the smuggling activities. The extent of border control contributes significantly with the migrant smuggling as well as the security related issues. If the border control is weak, then, it will stimulate smuggling activities, and if the control is strict, the migrants will employ agents to assist their entries simultaneously benefiting the smuggling syndicates. Migrant smuggling can be perceived as a critical trans-border crime at present. Even though migrant smuggling is based on voluntary basis and does not involve exploitation, but it actually exposes them into human trafficking crimes. Charges imposed by the syndicates are different and failures to pay, will lead them being abuse or sold to other parties. In addition, migrant smuggling takes place in terms of movement or documents. It means that, smuggling is not necessarily occurs at the non-gazetted border but it could also take place if they use the legal or gazetted entrance via the border, by using fake documents. Hence, the government needs to strengthen and increase the enforcement to prevent the widespread of smuggling activities. Policy that prevent smuggling activities and illegal migrants should be used as a deterrence and pose pressures to the syndicate. The government also need to use intelligence through cooperation with the neighboring countries.

\section{Acknowledgement}

We would like to show our gratitude to Universiti Utara Malaysia for funding and supporting us for this research in term of financial and administration aspects. We also thank to any parties especially respondents who involved in this research directly or indirectly. Your precious ideas, sincere responds and constructive comments are really fruitful in this research.

\section{References}

[1] Angelina Sinyang, "Ada PATI jadi majikan- Hishammuddin," (Illegal Migrants become employer by Hishamuddin) Utusan Malaysia, 21 September 2011.

[2] Azizah Kassim, 2012, Dasar Pekerja Asing di Malaysia (Foreign Worker Policy in Malaysia), Bangi, Publisher UKM.

[3] Brochmann , G. 1998. Controlling immigration in Europe. Nation state dilemmas in an International Context. In International Migration. Processes and interventions, edited by H. Van Amersfoort and J. Doomernik (eds), Amsterdam: Institute for Migration and Ethnic Studies, 22-42

[4] Cornelius, W. A \& Takeyuki Tsuda. "Controlling Immigration: The Limits of Government Intervention." In Controlling immigration: A Global Perspectives ( $2^{\text {nd }}$ ed.), edited by W.A. Cornelius et al., 3-48. Stanford, Carlifornia: Stanford University Press, 3-48, 2004

[5] Heckmann, Friedrich, 2007, Towards a better understanding of human smuggling, IMISCOE Policy Brief, No. 5. Amsterdam: International Migration

[6] Mohd Nasaruddin Parzi dan Wan Noor Hayati Wan Alias. "Kalau nak cepat, kena bayar lebih." ("If you want to fast, you have to pay more") Berita Harian, 16 November 2013

\footnotetext{
${ }^{11}$ Interview with immigration officers on the $21^{\text {st }}$ May 2010 at Bukit Kayu Hitam immigration Office, Kedah.
} 
[7] Petros, M., 2005, The cost of human smuggling and trafficking, Global Migration Perspectives, 31, GCIM, Geneva

[8] Piper, Nicole. 2004. Rights of Foreign Workers and the Politics of Migration in South-East and East Asia. International Migration Vol. 42(5), 71-96

[9] Shelley, Louise, 2014, Human smuggling and trafficking into Europe: A comparative perspective, Washington D.C: Migration Policy Institute

[10] Tholen, Berry, 2010, The changing border: Developments and risks in border control management of Western countries, International Review of Administration Sciences Vol 76 (2): 259-278

[11] Triandafyllidou, Anna, and Thanos Maroukis, 2012, Migrant Smuggling: Irregular Migration from Asia and Africa to Europe, Basingstoke, United Kingdom: Palgrave Macmillan.

[12] Wan Noor Hayati Wan Alias, Imigresen di sogok (Immigration be bribed), Berita Harian, 15 November 2013,

[13] ___ Penemuan kubur besar di sempadan Perlis (Mass grave discovered in Perlis border), Utusan Malaysia, 24 May 2015

[14] _. Pemansuhan VOA berkuatkuasa 16 Ogos 2010 (The abolition of VOA effective August 16, 2010). Utusan Malaysia. 13 August 2010

[15] Interview with Malaysian Maritime Enforcement Agency (MMEA), at Bukit Malut, Langkawi Island, 29th June 2010

[16] Interview with Malaysian Immigration Department of Kedah, at Bukit Kayu Hitam Immigration Office, 21 May 2010

[17] Interview with Border Regiment Officers at Border Regiment Office, Bukit Kayu Hitam, $9^{\text {th }}$ June 2010

[18] Interview with Zahari Abdul Aziz, Director at the Enforcement Unit, Malaysia Immigration Department, Malaysia Immigration Head Quarters, Putrajaya, $2^{\text {nd }}$ June 2014 